\title{
Pärtlirajust ja ilmapärimusest
}

\begin{abstract}
Mait Sepp
Teesid: Eesti kirderannikul on levinud rahvapärimus pärtlirajust - tormistest ilmadest, mis pidid igal aastal esinema pärtlipäeva (24. august) lähedasel ajal. Jõhvi ja Väike-Maarja ilmajaamas aastail 1966-2012 mõõdetud tuule kiiruste järgi otsustades on pärtliperiood (augusti lõpp ja septembri algus) pigem tuulevaikne. Samas tuleb selgelt välja, et keskmised tuulekiirused on viimastel kümnenditel järsult vähenenud; s.t "vanasti" oli pärtel kindlasti tuulisem.

Kas ilmapärimusi tasub uurida? Ühelt poolt on suurem osa rahvalikke ilmatarkusi laenatud teistest kultuuridest ja ka sünoptikas on neist vähe kasu. Teiselt poolt on ilmapärimused senini süstemaatiliselt läbi töötamata, kuigi need võivad anda hea sissevaate meie esivanemate maailmatunnetusse ja ehk ka kaudseid andmeid kliimaoludest.
\end{abstract}

Märksõnad: ilmavanasõnad, kliimamuutus, pärtlipäev, pärtliraju, rahvapärimus, tuulekiirus

\section{Sissejuhatus}

Käesoleva artikli kirjutamise algpõhjused on isiklikud. Nimelt on autori isa sünnipäev 25. augustil. Tavaliselt tähistame seda tema sünnikodus Aa külas. Sageli saab pidu peetud aias, vahel aga, kui ilm juhtub olema kehv, tuleb õnnitlejad mahutada asundustalu kitsastesse tubadesse. Meenub isa juubel 1989. aastal, mil sai arvukate külaliste tarvis ehitatud kilekatusega peotelk. Õhtu oli väga vihmane, vesi hakkas kogunema katuse servadesse, venitades kile sisse veeloigumullid. Keegi külalistest torkas ühe sellise mulli sõrmega läbi ja sai kaela ämbritäie vett. Iga kord kui sünnipäeva ajal sajab vihma või on ülemäära tuuline või muidu halb ilm, osatab autori ema, et näe, isa on sündinud pärtliraju aegu ja praegu möllabki pärtliraju. Olgu mainitud, et nii ema, isa kui ka mõlema suguvõsad pärinevad Lüganuse kihelkonnast, kus usk pärtlirajusse ja erinevad pärtlipäevaga seotud kombetäitmised on olnud eriti levinud (joonis 1). 


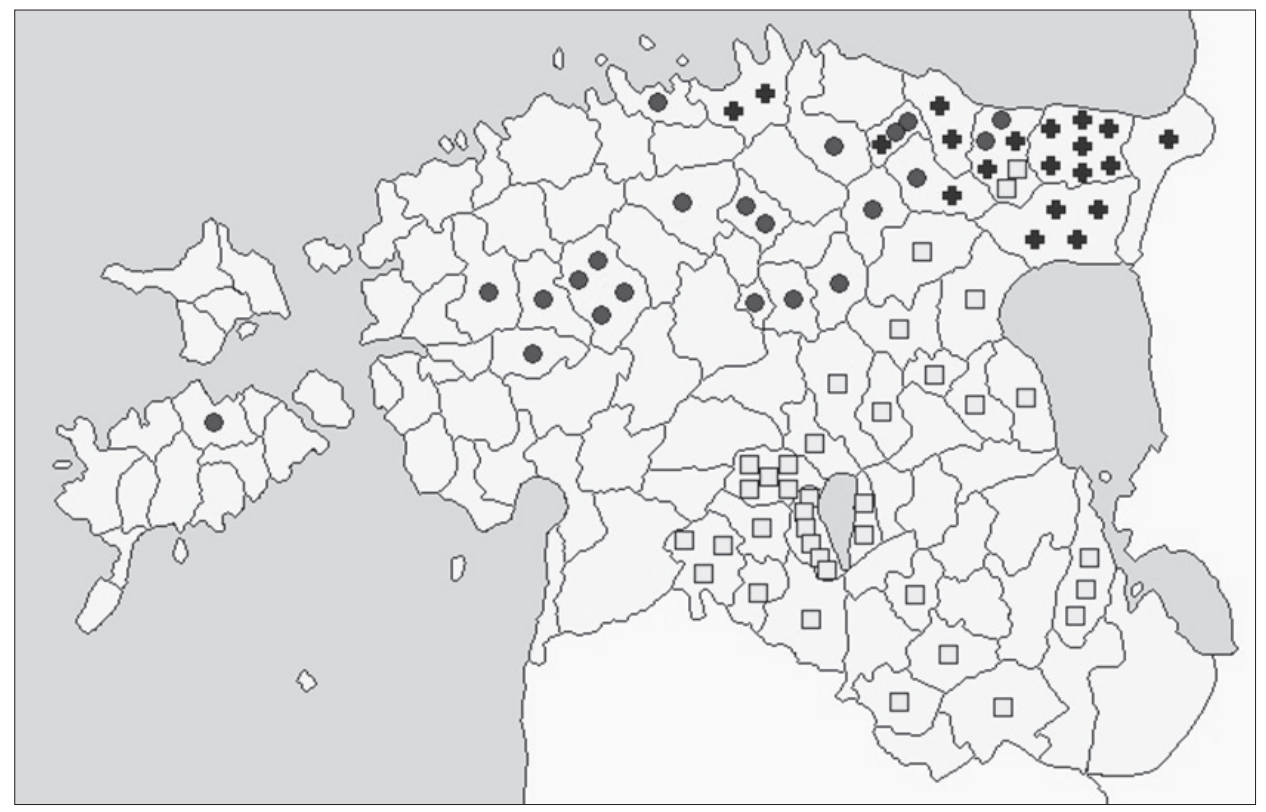

Joonis 1. Pärtlipäevaga seotud rahvapärimuste leviku kaart kihelkondade kaupa. Tähised joonisel:

- keskhommik kaob: hommikune tööaeg lühenes sedavõrd, et hommikusöögi ja lõuna vahele jääv keskhommikune söögikord jäeti ära;

+ pärtliraju: teated tormist pärtlipäeval või selle lähedasel ajal;

$\square$ rukkikülvi tabu: rukist tohtis külvata kolm päeva enne ja kolm päeva pärast pärtlipäeva. Allikas: http: / /www.folklore.ee/erk/items / show/34146 (Eesti rahvakalender).

Pärtlipäev - 24. august - on teatavasti pühendatud Jeesuse jüngrile Bartolomeusile. Legendide järgi rändas ta oma õpetaja usku kuulutama Indiasse ja Armeeniasse. Katoliiklikus traditsioonis on ta kõikide nahka käitlevate ametiesindajate kaitsepühak ja tema tunnustööriist on pikk nahalõikamise nuga. See sümboolika viitab tema elu hirmsale lõpule: apostel nüliti Kaspia ääres Derbendis elusalt ja löödi siis pea maha.

Virumaal on 24. august olnud rahvakalendri oluline tähtpäev (joonis 1). Pärtlipäevaga lõppes suvi. Algasid sügisesed tööd, lõikusaeg, viljade küpsemine, kapsas keeras sel päeval peasse. Pääsukesed lendasid minema. Pärtlipäev oli ka sügiseses rukkikülvis oluline tabupäev - sel päeval põllule minna ei tohtinud, kuid kolm päeva enne ja pärast pärtlit tuli kindlasti külviga tegeleda (Hiiemäe 1991: 75-100; Hiiemäe 2010: 241-242). Pärtlipäeva peeti kirderannikul sedavõrd tähtsaks tähtpäevaks, et vähemalt Jõhvi kihelkonnas üleskirjutatud rahvapärimuse järgi nimetati siin augustit pärtlikuuks (Viires 1993). 
Eesti kirderanniku rahvatraditsioonis käis pärtlipäevaga alati kaasas ka pärtliraju: hirmus torm, mis kestvat mitmeid päevi. Kui juhtus torm olema enne 24. augustit, oli see hea pärtel - raju kestis vaid kolm päeva. Sellega ei käinud kaasas tugevat, vilja lamandavat vihmasadu. Paha pärtel tuli aga pärast pärtlipäeva. See torm puhus kolm päeva ühtepidi, siis keeras tuulesuuna vastupidi ja rajus veel kolm päeva. Viljasaagile tegi see hirmsat kahju (Ahven 1957: 94; Hiiemäe 2010: 242). Pärtliraju kirjeldus, mida kirjandusallikates sageli korratakse (vrd Ahven 1957: 94; Hiiemäe 2010: 242), on sedavõrd detailne ja emotsionaalne, et ei jäta lugejates kahtlust: kirjeldatakse jutustaja enda poolt üle elatud sündmusi. Ka pärtlirajuga seotud vanasõnad, nagu näiteks Enne jääb pool talve taevasse, kui jääb ära pärtliraju või Pärtliraju ja kadrisula ei jäänud ühelgi aastal tulemata (Hiiemäe 1991: 95; Hussar et al. 1983: 767-768), viitavad oma kategoorilisusega väga kindlatele ilmastikusündmustele. Üldiselt sarnanevad pärtliraju kirjeldused meteoroloogilises mõttes tüüpilisele madalrõhkkonna möödumisele, mille korral puhub tuul pikka aega ühes suunas ja siis pöördub. Vastupidiselt augusti lõpus tavalistele tõusvatest õhuvooludest kujunevatele äikesetormidele, mis on nii ajas kui ka ruumis juhuslikku laadi ja suhteliselt lühiajalised, peaksid sellised tsüklonitega seotud tormid jätma tuulekiiruse aegridadesse selge statistilise jälje.

Rahvapärimuse kõrval võib viiteid pärtlirajule leida ka vanadest ajalehtedest. Näiteks Rakveres rikkus 1929. aasta 8. ja 9. septembri tormine ilm ära sealse luterikoguduse näitusmüügi (Virumaa Teataja, 10. september 1929). Samast lehenumbrist saame teada, et torm oli eriti ränk talunikele, kuna peksis maha veel valmiva suvivilja ja leotas läbi juba redelitele kuivama pandud saagi. Rajuga kaasnenud vihmasadu tekitas ka uputuse madalamates kohtades asunud loomalautades. Seda tormi nimetas Virumaa Teataja pärtlirajuks. Sama torm ajas Soomes, Tampere lahel aga ümber auriku, uppus vähemalt 77 inimest. Uudised Virumaa rannikut rüüstanud tormidest, mida ajalehtedes pärtlirajuks nimetati, jõudsid lugejateni ka 1937. ja 1938. aastal (Virumaa Teataja, 10. september 1937; Uudisleht, 29. august 1938).

Isegi Eesti ilukirjandusest võime leida viiteid pärtlirajule. Jüri Parijõgi alustab ühte oma kirjanikukarjääri esimestest jutustustest järgmiselt:

See oli tormine pärtlipäev. Kulbul ajas torm reidilt kaks laeva randa, lõhkus sadamasilda, purustas palju võrgukuure rannal ja tegi muudki kahju. Siis hukkus Pühakaril Norra purjekas ja Kulbu mehed käisid hingi päästmas, nagu ütles vana majakavaht Ankruvits. (Parijõgi 1927.)

1936. aastal avaldati ajakirjas Eesti Noorus novellikatke "Pärtliraju", millest võime lugeda: 
Kaarle tõmbas pikalt mööda parrast, iga õnarust hoolikalt tõrvaga leotades. Vedas mitmed korrad nagu paitades edasi-tagasi. "Jah tulevad rajud, siis peab olema tihe, ei siis korviga minda. Näe, pärtli-puhud varsti varnast võtta." (Niilas 1936.)

Pärtlirajust on kirjutanud ka meie poeedid.

Gustav Suits (1913):

Ju roobitsenud Pärtlipäeva rajud

puud esimestest koltund lehtedest;

maast käinud üle rängad, külmad sajud.

Marie Under (1931):

Me peesitanud soojas,

Ja nü̈̈d on suvi loojas -

Ei head too Pärtliraju iil.

Seega tekitasid kodused kinnitused ja kirjandusallikad huvi, kas selline asi, nagu pärtliraju on tõesti olemas? Kas Virumaa meteoroloogiliste mõõtmiste andmestikus on pärtlipäev või selle lähedane aeg tõesti keskmisest tuulisem? Käesolevas artiklis on analüüsitud tuulekiiruste statistikat ning arutletud küsimuse üle, kas ilmapärimuse uurimisel on perspektiivi?

\section{Andmed ja metoodika}

Virumaa tuulekliimat iseloomustavad kõige paremini Jõhvi ja Väike-Maarja meteoroloogiajaamas mõõdetud andmed. Kirde-Eestis on veel mitu ilmajaama, kuid näiteks Narva ja Narva-Jõesuu jaam on korduvalt kolinud ning Kunda jaam asub tuule mõõtmise mõttes ebasoodsas kohas. Seega analüüsitakse siin üksnes Jõhvi ja Väike-Maarja jaamas perioodil 1966-2012 standardsel $10 \mathrm{~m}$ kõrgusel mõõdetud tuulekiirusi. Tuulekiirused on mõõdetud iga kolme tunni järel (kell 0, 3, 6, 9, 12, 15, 18, 21) ja need kujutavad endast 10 minuti keskmist tuulekiirust täpsusega $1 \mathrm{~m} / \mathrm{s}$. Andmed on saadud Tartu Ülikooli geograafiaosakonna vanemteadur Ain Kullilt (2017), kes on Riigi Ilmateenistusest ja meteoroloogilistest aastaraamatutest kokku kogunud ja süstematiseerinud Eesti ilmajaamade tuulemõõtmiste andmed.

Tuulemõõtmiste puhul on üsna suureks probleemiks mõõtmiskohtade ja -metoodika sagedased muutused. Näiteks alles 1966. aastast hakati tuule parameetreid mõõtma kaheksa korda ööpäevas. Samal aastal hakati Jõhvi jaamas, mis alustas tööd küll juba 1926. aastal, tuule suunda ja kiirust mõõtma tuulelipu asemel anemorumbomeetriga. Väike-Maarja meteojaam asutati 
1962. aastal, kuid anemorumbomeetrile mindi üle alles 1973. aasta novembris. Kui tuulelipu puhul kasutatakse tuule kiiruse mõõtmiseks tuule suunaga risti kõikuvat metallplaati, siis anemorumbomeeter registreerib ümber oma telje pöörleva tiiviku pöörlemiskiirust. Anemorumbomeetri mõõtmistulemused on tuulelipust täpsemad, seda peamiselt suuremate tuulekiiruste osas. Seega teoreetiliselt peaksid pärast 1973. aastat Väike-Maarjas mõõdetud ekstreemsed tuulekiirused olema suuremad. Praktikas aga sellist vahet ei ilmne (Kull 2017).

2003. aastal jaamad automatiseeriti ja andmed on nüüd kättesaadavad iga tunni kohta $0,1 \mathrm{~m} / \mathrm{s}$ täpsusega. Siin on aga analüüsi ühtluse huvides ka hilisemate mõõtmiste puhul kasutatud vaid klassikalise kaheksa vaatluskorra andmeid ja tuulekiirust täpsustasemel $1 \mathrm{~m} / \mathrm{s}$.

Esimeses järjekorras sai arvutatud aasta iga päeva kohta pikaajaline (19662012) ööpäeva keskmine tuule kiirus. Siin kasutatud Virumaa keskmine tuule kiirus on Väike-Maarja ja Jõhvi jaamade aritmeetiline keskmine. See annab meile taustateavet tuulekiiruste aastase kõikumise kohta. Aastate-vahelise varieeruvuse tasandamiseks ja seega aastasisese muutlikkuse paremaks visualiseerimiseks on joonisel 2 tuulekiiruste pikaajaliste ööpäeva keskmiste kõrval esitatud ka kuuenda astme polünoomkõver. See silub aegrea hüplikkust, mis on sageli tingitud mõnest juhuslikult esinenud sündmusest (tuulekiiruste puhul näiteks mõnest tugevamast tormist) ja võimaldab paremini näha protsesside üldist käiku. Polünoomkõvera puhul leiab arvuti antud andmete alusel kas näiteks ruutfunktsiooni või praegusel juhul kuuenda astme funktsiooni, mille alusel arvutatud kõver on tegelike andmete graafikule kõige lähedasem. Teise astme polünoomi ehk ruutvõrrandi graafik on suhteliselt lihtne parabool. Mida rohkem astmeid võrrandisse lisada, seda keerukamaks muutub polünoomkõver ja seda paremini kajastab see aegrea-sisest muutlikkust. Seega praegusel juhul on tulemiks tuule kiiruse aastase käigu idealiseeritud mudel.

Iga päeva kohta on välja arvutatud ka standardhälve. Nende näitajate alusel saab otsustada, kas pärtlipäev ja selle lähedaste päevade tuulekiirused erinevad kuidagi eriliselt aasta tuulekiiruse loomulikust käigust.

Järgnevalt said tuuleandmetest välja sorditud need päevad, mil vähemalt ühel mõõtmiskorral tõusis kümne minuti keskmine tuule kiirus üle $15 \mathrm{~m} / \mathrm{s}$. Selle tuule kiiruse ületamist peetakse meteoroloogias traditsiooniliselt tormiks. Eraldi analüüsitakse ka päevi, mil vähemalt ühel mõõtmiskorral oli tuule kiirus $10 \mathrm{~m} / \mathrm{s}$ ja enam ning $8 \mathrm{~m} / \mathrm{s}$ ja enam.

Metoodilises mõttes tuleb aga tähele panna ja eriti loodusennetega seotud rahvakalendri tähtpäevade puhul suure ettevaatusega suhtuda 1918. aasta kalendrireformi. Ligi kahenädalane nihe tähendab looduses hoopis teistsuguseid olusid. Antud juhul tähendab reform seda, et vana (Juliuse) kalendri järgne pärtlipäev on uue (Gregoriuse) kalendri järgi 7. septembril. Seda kuupäeva 
on kasutatud vana pärtlipäevana ka näiteks artiklis "Enne jääb pool talve taevasse, kui jääb ära pärtliraju" (Sepp 2013a). Ent 19. sajandil, mil suur osa rahvapärimust üles kirjutati, oli kahe kalendri vahe 13 päeva. Nii on ka siin vana kalendri pärtlipäevaks võetud 6. september.

Jõhvi kandi rahvatarkuste järgi (Hussar et al. 1983: 767) ei pea pärtliraju esinema ainult 24. augustil, vaid nii kutsuti kõiki torme, mis möllavad kuni kaks nädalat enne või pärast pärtlipäeva. Seetõttu on siin vaatluse all 29 päeva tuuleolud: pärtlipäev + 14 päeva enne pärtlipäeva (hea pärtel) + 14 päeva pärast pärtlipäeva (paha pärtel). Kasutame kahte pärtliperioodi: 24. august ja ajavahemik 10. august - 7. september on uus pärtel ning 6. september koos perioodiga 23. august - 20. september on vana pärtel.

\section{Tulemused}

Tuule kiirusel on selge aastasisene käik (joonis 2). Sügisel ja talvel on tuul tugevam, suvel nõrgem, saavutades oma suhtelise miinimumi juuli teisel poolel. Augustis ja septembris tuule keskmine kiirus tasapisi tõuseb. Tuulekiiruse statistika puhul tuleb arvestada väga suure päevade ja aastate vahelise varieeruvusega. Nii on näiteks antud juhul pikaajaline aasta keskmine standardhälve keskmiste tuulekiirustega võrreldes suhteliselt suur: $2,4 \mathrm{~m} / \mathrm{s}$, (üksikute päevade standardhälve jääb vahemikku 1,6-3). Ka tuleb tähele panna, et kuigi iga päeva (v.a 29. veebruar) keskmine on arvutatud 47 aasta 376 mõõtekorra keskmisena, on ekstreemsetel üksikväärtustel statistikale väga suur mõju. Näiteks joonisel 2 torkab enne pärtliperioodi silma üksik piik 7. augustil. See on kuulsa 1967. aasta 6. ja 7. augustil möllanud tormi jälg pikaajalises ööpäeva keskmises tuule kiiruses. Ka näiteks 15. septembri piiki saab seletada ühe konkreetse madalrõhkkonnaga 1996. aastast.

Kui vaadelda aga pärtliperioode tuule kiiruse modelleeritud aastase käigu ehk polünoomjoone võrdluses, võiks öelda, et nii uus kui ka vana pärtel on pigem silmatorkavalt tuulevaiksed.

Nagu 7. augusti 1967 ja 15. septembri 1996 tormi näidetest järeldub, jätavad erakordsed tormid sageli selge statistilise signaali pikaajalisse keskmisse. Siiski keskmiste arvutamine pigem tasandab erakordsete sündmuste jälge aegreas. Sestap on mõttekas vaadelda pärtliperioodi torme üksikjuhtumitena. Ühtlasi annab see võimaluse uurida muutusi pärtlirajude esinemissageduses.

Paraku tuleb antud juhul arvesse võtta seda, kuidas tormi või raju defineerida, ja see ei ole lihtne. Vanasõnade puhul oleks mõistlik võtta aluseks keeleteaduslikud allikad ja vaadata, mida üks või teine tormist ilma tähistav sõna sisuliselt tähendab. Ent näiteks Andrus Saareste "Eesti keele mõistelise 


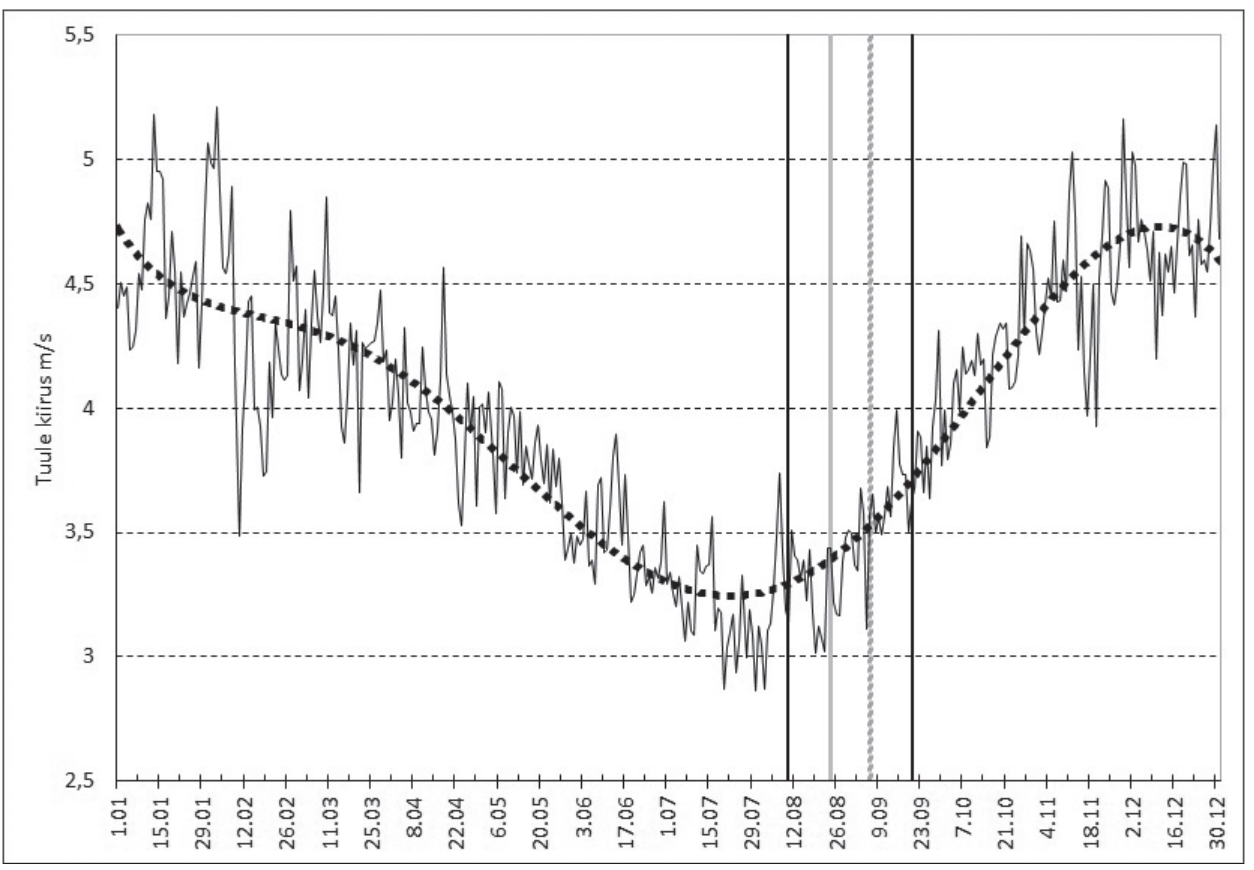

Joonis 2. Tuule kiiruse pikaajaline aastane käik Virumaal Jõhvi ja Väike-Maarja keskmisena. Must pidev joon: pikaajaline ööpäeva keskmine perioodil 1966-2012; punktiirjoon: 6. astme polünoom. Mustade tulpadega on ära märgitud pärtliperioodide piirikuupäevad: 10. august - uue pärtli varaseim ja 20. september - vana pärtli hiliseim kuupäev. Halli pideva joonega on tähistatud 24. august ehk uus pärtel ja halli katkendliku joonega 6. september ehk vana pärtel.

sõnaraamatu indeksitest" (http://www.eki.ee/dict/saareste/) leiame mõisteterühma "torm" alt 44 ja "tuul" alt 304 artiklit. Mis tähenduslik vahe on ühel või teisel nendest sadadest sõnadest, vajab eraldi uurimist, ning see väljub käesoleva artikli raamidest ja autori kompetentsist. Saareste tuule ja tormi artiklite ohtrus aga viitab ilma kirjeldavate sõnade nüansirohkusele. Nii on Mall Hiiemäe (2015) kirjutanud, et "Kirde-Eesti rannikumurde meru ja möru kuuluvad jõulisema tähendusväljaga nimetuste hulka, kui seda on pelgalt maru." Ilmselgelt on ka maru ja raju vahel erinev tähendusväli, kuid kuidas väljendada seda tuule kiirusena meetrites sekundis? Huvitav on aga täheldada, et raju (ka rajo ja roju) oli tormi tähistava sõnana levinud peamiselt just Virumaa idapoolsetes kihelkondades (VMS).

Meteoroloogias hinnatakse tuule tugevust klassikaliselt niinimetatud Beauforti skaala järgi. See on 19. sajandi keskpaigast kasutusel olev empiiriline 
skaala, milles tuule kiirus (sisuliselt küll ilm) jagatakse 13 klassi, vastavalt sellele, kas on tuulevaikus ( 0 klass), tuul liigutab puudel lehti ja tekitab kergeid laineid, või murrab oksi ja paneb merevee vahutama. Skaala kõrgeim ehk 12. klass on orkaan, mille korral on tuule kiirus suurem kui $32,7 \mathrm{~m} / \mathrm{s}$. Sellise 12pallise tuule tugevuse korral on merel hiiglaslikud lained, maismaal metsad laastatud ja ehitistel laialdased purustused.

Beauforti skaala järgi nimetatakse rajuks tuule kiiruse vahemikku $17,2-$ $20,7 \mathrm{~m} / \mathrm{s}$ ja tormiks $20,8-24,4 \mathrm{~m} / \mathrm{s}$; s.o mainitud skaala 8 ja 9 palli. Siin vaadeldavate aastate suurim mõõdetud tuule kiirus pärtliperioodidel on mõlemas jaamas aga vaid $16 \mathrm{~m} / \mathrm{s}$ (6. septembril 1973). Olgu mainitud, et Lääne-Eestit rüüstanud 1967. aasta augustitormi ajal mõõdeti tuule maksimaalseks $10 \mathrm{mi}-$ nuti keskmiseks kiiruseks nii Jõhvis kui ka Väike-Maarjas samuti vaid 16 m/s, kuid seda mitmel mõõtekorral järjest. Näiteks toodud 15. septembri 1996 tormi kiirused jäid mõlemas jaamas vahemikku 9-11 m/s. Seega polnud vaadeldaval 47 aastal pärtliperioodil ühtegi sündmust, mida Beauforti skaala järgi saaks nimetada rajuks, veel vähem tormiks. Ka traditsioonilise $15 \mathrm{~m} / \mathrm{s}$ järgi võib rääkida vaid ühest pärtlirajust - juba mainitud 6. september 1973. Olgu täpsustuseks üle korratud, et siinkohal me manipuleerime 10 minuti keskmise tuule kiirusega. Lühiajaliselt ehk puhanguti võivad tuulekiirused nende sündmuste ajal ulatuda 25 ja rohkem $\mathrm{m} / \mathrm{s}$.

Niisiis, piisava valimi saamiseks tuleb raju defineerimise latti oluliselt alandada ja rajajooneks võtta $10 \mathrm{~m} / \mathrm{s}$. Seegi on suhteliselt suur tuulekiirus (Beauforti skaalal 5-6 palli), mis paneb traadid undama ja keerab viletsamad vihmavarjud tagurpidi. Lisaks tuleb arvestada, et mõlemad meteojaamad asuvad rannikust suhteliselt kaugel (Jõhvi linnulennult ca $10 \mathrm{~km}$ ja Väike-Maarja $48 \mathrm{~km}$ ). See aga tähendab, et rannal ja merel võib samal ajal möllata üsna korralik torm.

Kui võtta aluseks uue pärtli periood, esines aastatel 1966-2012 Jõhvis tuule kiirus $10 \mathrm{~m} / \mathrm{s}$ ja enam kokku 38 ja Väike-Maarjas 29 päeval. Seejuures täpselt pärtlipäeval (24. augustil) oli Väike-Maarjas tuuline vaid kolmel (1966., 1973., 1989.) ja Jõhvis ühel (1973.) aastal.

Järgnevalt vaatleme aga detailsemalt vana pärtli perioodi, sest sellel ajal valitsevad loodusolud vastavad pärtlipäeva pärimustest kajavatele suvelõpu meeleoludele oluliselt paremini. Ent ka vana pärtli perioodil on tuule kiirus väga harva $10 \mathrm{~m} / \mathrm{s}$. Analüüsitava 10904 mõõtmiskorra kohta esines tuule kiirust $10 \mathrm{~m} / \mathrm{s}$ ja enam mõlemas jaamas vaid $c a 90$ korral. See tähendab, et Jõhvis oli vaadeldaval perioodil 53 ja Väike-Maarjas 50 tormist päeva. Täpselt pärtlipäevale (6. septembrile) langes rajune ilm vaid kahel aastal: 1973 ja 1974. Tuleb ka öelda, et sellist väga tugeva tuulega ilma ei esine iga aasta pärtliperioodil. Samas on mõnel aastal pärtlirajusid mitu - näiteks 1966. aastal kummaski jaamas lausa viis. 
Seega, et saada tugeva tuulega sündmusi iga aasta pärtliperioodi, tuleb tuulekiiruse latti veelgi allapoole lasta. Siin tekib aga metodoloogiline küsimus, mida võtta selleks kriteeriumiks, mille järgi piiri nihutada? Võib näiteks aluseks võtta tuule kiiruse esinemissageduse jaotuse ja lähtuda 95. protsentiilist, mis on loodusteaduses traditsiooniline piir harvaesinevate sündmuste eristamiseks. Lihtsustatult võib 95. protsentiili lahti seletada kui väärtust, millest 95\% mõõtmisi omab väiksemat väärtust, kui antud väärtus. Nii Jõhvi kui ka Väike-Maarja vana pärtli perioodi 95. protsentiiliks on $7 \mathrm{~m} / \mathrm{s}$. Selle tuule kiirusega (vastab Beauforti skaala 4 pallile ehk mõõdukale tuulele) hakkavad küll tolm ja vabad paberilehed lendlema ning merele tekivad mõned lainejänesed, kuid tormiseks ei saa sellist ilma kuidagi pidada. Sestap võtame siin aluseks Beauforti skaala 5 palli väikseima tuulekiiruse $8 \mathrm{~m} / \mathrm{s}$. Üldiselt tuulevaikse augusti lõpu ja septembri alguse oludes on isegi sellise tuulekiirusega päev kindlasti tähelepanuväärne. Selle taseme puhul ilmnevad üsna hästi ka need mitu päeva kestvad pärtlirajud, millest vanarahvas on rääkinud.

Joonisel 3 on kombineeritud Jõhvi ja Väike-Maarja tuulekiiruse andmeid ja leitud, mitmel vana pärtli perioodi päeval oli Virumaal tuuline. Antud joonise puhul on pärtlirajuks defineeritud pärtliperioodi päev, mil tuule kiirus kas Jõhvi või Väike-Maarja või mõlemas jaamas korraga on vähemalt ühel mõõtmiskorral võrdne või suurem $8 \mathrm{~m} / \mathrm{s}$.

Kõigepealt tuleb tähele panna, et päris pärtlipäeval (6. septembril) esines tuulist ilma kas Väike-Maarjas või Jõhvis või mõlemas kohas korraga vaid 11 juhul. Samas tuleb öelda, et tõesti pole veel olnud aastat, kus joonise koostamise aluseks võetud definitsiooni järgi ei oleks esinenud pärtliraju. Selgelt on aga näha, et pärtlirajude esinemissagedus on 47 aastaga kiiresti vähenenud. Kui 1966. aastal oli vaadeldavast 29 pärtliperioodi päevast Virumaal kokku 14 rajust päeva (kuus hea ja kaheksa paha pärtli päeva), siis 2012. aastal vaid kolm (üks hea ja kaks paha pärtli päeva). Jõhvi puhul võib sellise vähenemise taga kahtlustada asjaolu, et jaama lähedusse on ehitatud Kohtla-Järve Ahtme linnaosa. Ent kuna ka Väike-Maarja tuulekiirused on vähenenud üsna drastiliselt, siis tähistavad need tendentsid pigem kliimamuutusi. Üheks suundumuseks on muuhulgas see, et kui 1960-70. aastatel esines raju enamikul kordadest mõlemas jaamas samal päeval, siis viimasel ajal on tuuline kas Väike-Maarjas või Jõhvis. Juba näiteks toodud 1966. aasta 14 rajupäevast kümme olid tuulised nii Ida- kui ka Lääne-Virumaal. 2012. aastal oli kolmest tuulisest päevast vaid üks mõlemas jaamas ühine. 


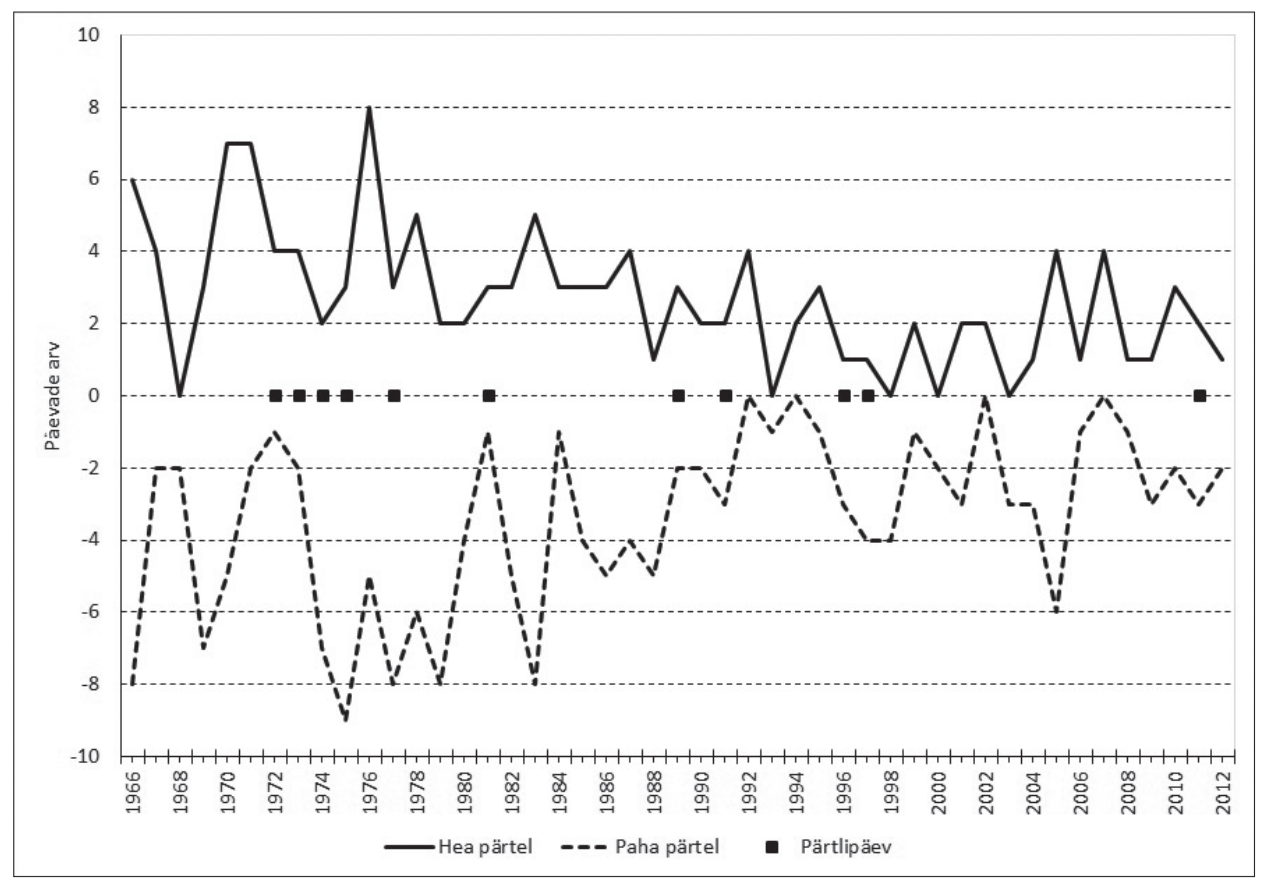

Joonis 3. Päevade arv, mil Virumaal (Väike-Maarjas ja Jõhvis või mõlemas jaamas korraga) esines vana pärtli perioodil (23. august - 20. september) pärtliraju: päev, mil tuule kiirus kas Jõhvis või Väike-Maarjas või mõlemas jaamas korraga oli vähemalt ühel mõõtmiskorral võrdne või suurem kui $8 \mathrm{~m} / \mathrm{s}$. Mustade nelinurkadega on tähistatud need aastad, mil pärtliraju esines pärtlipäeval (6. septembril). Paha pärtel (rajud, mis esinevad pärast pärtlipäeva) on esitatud negatiivses skaalas. S.t näiteks 1966. aasta väärtus - 8 tähendab, et paha pärtli perioodil (7.-20. septembrini) oli pärtliraju kokku kaheksal päeval.

\section{Arutelu ja järeldused}

Kui võtta aluseks formaalsed tuule kiiruse kriteeriumid, mille järgi ilmateadustes piiritletakse tormi ja raju, võib järeldada, et vaadeldaval 47 aastal on pärtliperioodil esinenud vaid üks pärtliraju. Kui alandada raju defineerimise piire 10 meetrini sekundis, siis tugeva tuulega päevade arv küll suureneb, kuid igasse aastasse selliseid juhtumeid siiski ei jätku (vt Sepp 2013a: joonis 5). Üldse (eriti viimastel kümnenditel) on augusti lõpp ja septembri algus olnud pigem silmatorkavalt tuulevaikne periood. Kui aga silmas pidada meil harilikult juulist augustini valitsevat suhtelist tuulevaikust, võib iga tolmu keeru- 
tav või traate undama panev tuuline päev tunduda rajuna. Kui aga lähtuda ameerika kirjaniku Darrell Huffi (1954) sententsist: "Kui andmeid piisavalt kaua piinata, tunnistavad need üles ükskõik mida," ja alandada tuule kiiruse piiri $8 \mathrm{~m} / \mathrm{s}$, siis võib tõesti öelda, et pärtliraju on midagi sellist, mis esineb igal aastal. Sellisel juhul võib tõesti iga augusti lõpu või septembri kontrastselt tuulist ilma nimetada pärtlirajuks.

Teisalt tuleb tähele panna, et pärtliraju võib olla langenud kliimamuutuste ohvriks. Siin vaadeldava perioodi alguses on veel ka augustis ohtralt tuuliseid ilmasid, millest mõndagi võib ametlikult tormiks nimetada. Uue sajandi alguses on rajuilmasid Virumaal vaid mõned üksikud. Sellise tendentsi üheks põhjuseks võiks tuua muutused maastikul: metsasuse üldine kasv Eestis ja Jõhvi puhul ka linnaehitus. Olulisem põhjus on aga kliima soojenemine, mille tulemusena on klimatoloogilise sügise algus viimase poole sajandi jooksul peaaegu kogu Eestis nihkunud kuni kaks nädalat hilisemaks (Tarand et al. 2013: 397). Samuti võib siis esimese sügistormi esinemine olla ajapikku hilisemaks liikunud. Sellega võiks seletada näiteks hea pärtli vähenemise tendentsi. Ent siin on näha märke keerukamatest muutustest atmosfääri tsirkulatsioonis ja sellest tulenevalt ka üldises tuulerežiimis. Trendid Euroopa tuulekliimas on täis vastuolusid. On töid, mis näitavad tuule kiiruse üldist ja eriti suurte tuulekiiruste vähenemist viimastel kümnenditel (Smits et al. 2005; Vautard et al. 2010; Keevallik 2011). Teisalt leidub uurimusi, millest järeldub, et tuule kiirus on hoopis kasvanud, seda peamiselt läänetuulte arvel (Chen et al. 2006; Tomingas 2002). Eesti puhul on näiteks Tarand et al. (2013: 441-442) toonud välja, et mõnes Lääne-Eesti jaamas on perioodil 1960-2010 tormipäevade arv üldiselt vähenenud, aga nende kõrval olevates hoopis suurenenud. Pärtliraju kontekstis on huvitav tähele panna, et kõigis analüüsitud jaamades on tormipäevade arv vähenenud just augustis ja septembris (vt Tarand et al. 2013: tabel 5.4.2).

Tuleb tunnistada käesoleva statistilise analüüsi teatud nõrkusi. Lõppude lõpuks ei anna eelnev kindlat vastust, kas pärtliraju on siis olemas, või on see vaid tühi rahvajutt. Võib-olla kunagi oligi pärtliraju tõesti igasügisene nuhtlus? Kuigi varasemaid tuulekiiruse mõõtmisi on tänapäevastega keeruline kõrvutada, on ju mõõtmisi siiski tehtud ja vähemalt kvalitatiivsel tasemel (tuulevaikne-tuuline-tormine päev) oleks rajude analüüs täiesti võimalik. Ilmateaduste seisukohalt saab pärtliraju edasi uurida ka näiteks sünoptilisel tasemel, s.t vaadelda, millise sünoptilise sündmusega meil suvi lõpeb. On selleks tõesti mõni kindel torm, mis pumpab siia suhteliselt jahedamaid õhumasse, või toimub päeva lühenemisest tingitud järkjärguline jahtumine? Klimatoloogia mõttes annaks see meile veel ühe võimaluse hinnata, kuidas on ilmastik muutunud.

Samas tekib siin õigustatud küsimus: on's ilmavanasõnade analüüsimisel mõtet? Milliseid teadmisi või kasu see võiks anda? 
Nendele küsimustele vastamisel tuleb silmas pidada mitut aspekti. Kindlasti ei saa rahvajutte, s.h ilmavanasõnasid tõesti ülemäära tõsiselt võtta. Kui diplomaatilisemalt väljenduda, siis nendes on mitmeid metodoloogilisi probleeme: alates sellest, et mõnikord on jutustajad rahvapärimuse kogujatega ilmselt nalja teinud, lõpetades sellega, et suurem osa ilmavanasõnadest on meil laenud teistest kultuuridest (Sepp 2013b). Ka pärtliraju traditsioon on Kirde-Eestisse jõudnud arvatavasti Soome kaudu germaani rahvastelt (Hiiemäe 2010: 241). Sageli pärinevad nii-öelda laialt levinud rahvalikud ilmatarkused 19. sajandil maarahva hulgas väga populaarsetest kalendriraamatutest (Baran 2016). Sellised raskused pole aga Eesti folkloriste takistanud põhjalikult analüüsimast imemuinasjutte ja nende päritolu (nt Toomeos-Orglaan 2003; 2011). See, kuidas toimivad kultuuridevahelised kontaktid, olgu need siis imemuinasjuttude või ilmatarkuste laenamiste tasemel, on ka tänapäeva globaliseeruvas maailmas oluline uurimisobjekt.

Niisiis, miks mitte uurida rahvatarkusi ilma kohta? Seda enam, et niiöelda ilmavanasõnasid on igal rahval, sealhulgas ka eestlastel, ohtralt. See on iseenesest loomulik, sest peamiselt põllumajandusega seotud rahvale oli ilma ennustamine eluliselt oluline. Ka tänapäeval võiks tulevase suve ilmastiku täpse ettekuulutuse pealt teenida üsna kopsaka summa raha. Agraarses ühiskonnas oli aga ilmastiku ja saagi ennustamine suures osas elu ja surma küsimus. Vale külviotsus kevadel võiski tähendada järgmisel talvel nälga. Ilm ja ka ilmaended olid eestlastele sedavõrd olulised, et need olid lausa mitmete argielutavade osa: näiteks öeldi, et kui kõik taldrikud tühjaks süüakse, siis tuleb järgmisel päeval ilus ilm (Tedre 2015). Seega peaks ilmavanasõnades olema akumuleerunud rahva sajandite-pikkune kogemus. Sellisel juhul võiksid need, kui kaudsed ilmastikuandmed, huvi pakkuda ka klimatoloogia seisukohalt.

Siiski, vaatamata sellele, et ilmaga seotud rahvatarkusi on Eestis talletatud kümneid tuhandeid (Proodel \& Mürk 1970: 167; Hiiemäe 2007: 314), on neid suhteliselt vähe uuritud ja sellega on peamiselt tegelenud loodusteadlased. Senini praktiliselt ainus põhjalikum ilmavanasõnade analüüs ilmus 1920. aastal August Tõllasepa sulest (Tõllasepp 1920). See raamat sisaldab aga ohtralt ajastule omast moraalitsemist: rahvatarkused on küll väärt vanavara, mida koguda, kuid praktilist kasu ei maksa nendest otsida; vanasõnade järgi ilmaennustus on pigem ebausk, mis ei sobi tänapäevasesse, teaduskesksesse maailmapilti: "Suuremal jaol neist [vanasõnadest] ei ole teaduslist väärtust." Üsna samalaadset mõneti üleolevat suhtumist võib täheldada ka 20. sajandi esimesel poolel tegutsenud teiste maade vanasõnauurijate puhul (Hazen 1900; Taylor 1931). Meteoroloogide Henry Allen Hazeni ja August Tõllasepa (Tõllassepa) suhtumist võib mõista, sest mõlemad olid oma maal, vastavalt siis USAs ja Eestis, ilmateaduste (meteoroloogia, klimatoloogia, atmosfääri 
füüsika, sünoptika jne) pioneeride hulgas. Olukorras, kus meteoroloogia oli alles iseseisva teadusena sündimas, oli võitlus konkureerivate rahvalike ilmaennete ja pseudoteadustega omal kohal. Samas tunnistas August Tõllasepp juba oma raamatu eessõnas, et meteoroloogiateadused lihtsalt pole veel nii arenenud, et kõiki vanasõnu analüüsida (Tõllasepp 1920: 8). Nüüd, peaaegu sada aastat hiljem, võiks olukord olla muutunud: kui Hazeni ja Tõllaseppa aegadel võttis ilmaandmete statistiline uurimine aega nädalaid, siis praegu on see arvutiga mõne tunni või paari päeva küsimus.

Tõllaseppa meteoroloogikarjäär ja flirt ilmavanasõnadega jäi 1920. aastatel lühikeseks (Pae \& Tammiksaar 2016). Põgusalt käsitles ta ilmavanasõnade teemat ka oma Nõukogude vangilaagris alustatud ja pensionipõlves lõpetatud raamatus "Meteoroloogia kõigile". Siingi kutsub Tõllasepp üles suhtuma ilmavanasõnadesse, kui ilmade ennustamise vahendisse, ettevaatusega (Tõllasepp 1960: 210). Rahvalike ilmatarkustega on flirtinud teisedki Eesti loodusteadlased. Näiteks on muuhulgas rahvakultuuri kogumisega tegelenud Gustav Vilbaste kirjutanud viljasaaki puudutavatest ilmaennetest (Vilbaste 1944). 1970. aastal kirjutasid lühikese peatüki ilmatarkustest folklorist Mall Proodel (Hiiemäe) ja klimatoloog Heino Mürk (Proodel \& Mürk 1970). Sarnaselt Tõllasepa (1920) raamatule antakse selleski kirjatükis mõnedele rahvatarkustele ratsionaalseid seletusi. Samas öeldakse ka, et paljusid ilma kohta käivaid tähelepanekuid tuleks veel loodusteaduslikult uurida. Samuti on mitmeid vanarahva tähelepanekuid ilma ja selle ennustamise kohta klimatoloogi vaatevinklist käsitlenud Andres Tarand (2004). Rahvalike ilmatarkuste üle on oma kirjatükkides sageli arutlenud ka klimatoloog Ain Kallis.

Meie rahvapärimuse uurijad on ilmavanasõnadega tegelenud pigem fragmentaarselt. Võib-olla on põhjus selles, et ilma kohta käivad rahvatarkused ei taha hästi liigituda klassikaliste vanasõnade alla (Dundes 1984: 45; Krikmann 2001; Baran 2016; Grzybek 2016). Teiseks tundub, et folkloristid võtavad endiselt liiga tõsiselt Tõllasepa ja tema kaasaegsete sõnu nagu ei oleks ilmavanasõnadel teaduslikku väärtust (vt Hiiemäe 2007: 314). Need on ilmselt põhjused, miks ka rahvusvahelises teaduskirjanduses ei ole üleliia palju töid ilmavanasõnadest. Teadustööde andmebaasides Thomson Reuters Web of Science (http://webofknowledge.com) ja Scopus (https://www.scopus.com) võis käesoleva artikli kirjutamise ajal (veebruar 2017) märksõnade weather proverb, weather lore ja weather sayings järgi leida suurusjärgus 80 kirjet. Neist umbes veerandsada on ilmunud viimase paarikümne aasta jooksul, aga ligi 50 kirje puhul on avaldamisaasta 19. sajandis.

Eesti folkloristidest on ilmavanasõnu kõige põhjalikumalt käsitlenud Mall Hiiemäe (nt Proodel \& Mürk 1970; Hiiemäe 2007: 314-318; pärtliraju kohta vt Hiiemäe 1991: 75-100; Hiiemäe 2010: 241-242; Hiiemäe 2015), kuid ka tema 
on neid sagedamini vaadelnud vaid osana mõne rahvakalendri tähtpäeva kombestikus. Loodetavalt on olukord selles vallas muutumas, kuna näiteks Anneli Baran (2016) on kokku pannud sissejuhatava ülevaate Eesti rahvalikest ilmatarkustest. Tema kirjutises markeeritakse ära mitmed uurimissuunad, mida folkloristika seisukohalt tuleks edaspidi põhjalikumalt käsitleda: ilmatarkuste klassifitseerimine, andmeallikad, ilmavanasõnade levimine kalendritest rahva sekka, erinevate keelendite esinemissagedus vanasõnades ja nende võrdlemine teiste rahvaste vanasõnadega (Baran 2016). Seega on rahvalike ilmatarkustega vaja tegeleda kasvõi ainult seetõttu, et see on väheuuritud valdkond. Seejuures peaks n-ö jäme ots olema kultuuriteadlaste käes, kuna ilmapärimust tuleks pigem tõlgendada kui ilmastiku ja kliima mõjude sotsiaalset ja kultuurilist peegeldust (Hirschfelder 2012). Ilmateadused saavad siin pakkuda vaid teatavat loodusteaduslikku tausta.

Üks, mida rahvalike ilmatarkuste uurimine meile anda võib, on teatud sissevaade meie esivanemate maailmatunnetusse. Näiteks paistab mitmest Eestis väga levinud vanasõnast välja ettekujutus, et aasta peab olema termilises tasakaalus: kui talv on külm, siis peab suvi olema soe ja vastupidi, kui talv on soe, siis suvel on vilets ilm. Muide, sedalaadi vanasõnad on paelunud paljusid loodusuurijaid (vt Tõllasepp 1920; Vilbaste 1944; Proodel \& Mürk 1970; Tarand 2004). Andres Tarand (2004) on oma arvutustes leidnud, et statistilises mõttes sellist talve-suve seost pole. Olgu mainitud, et aastaaegade omavaheliste seoste analüüs on siiski klimatoloogias tõsiseltvõetav uurimisteema (Tehver 1999; Kaasik 2003). Talve-järgi-suvi vanasõnad on samuti laenud ning nende paikapidamatust tõestas juba Saksamaa meteoroloogia üks pioneere professor Georg Gustav Hellmann (Tõllasepp 1920: 34). Samas annavad need siiski vihje, mismoodi kujutasid eestlased ette ilmastikku ja selle toimimist enne seda, kui sündisid meteoroloogia ning regulaarsed ilmateated. Võib ju arutleda, et argiarvamuseks (Järv 1997) muutusid peamiselt sellised laenkõnekäänud, mis võimaldasid kohalikku ilmastikku paremini seletada või sobitusid siinsete inimeste maailmatunnetusega.

Veel üks küsimuste ring, millele vastamine võimaldaks vanarahva ilmatarkusi kasutada ka kaudse andmeallikana ilmateadustes, on seotud nende ilmumise ja levimise ajaga. Nagu mainitud, on pärtliraju puhul ilmne, et Eesti kirderannikule jõudis see mõiste Soomest. Virumaa rannik oli sõbrakaubanduse kaudu väga tihedalt seotud Soome rahvakultuuriga. Ent millal see pärimus meie rannikule jõudis? Kui nii-öelda "aegade algusest”, siis võib pärtliraju traditsioon olla iseenesest huvitav mälestis sellest, millise meteoroloogilise sündmusega kirderanniku rahvas suve lõppu märgistas. Kui aga pärtliraju muutus Kirde-Eesti kihelkondades ootamatult populaarseks teatud ajaperioodil, võib see olla märgiks, et sellal kimbutasid Virumaad augustis-septembris regulaar- 
sed tormid. Tormid, mille markeerimiseks sobis hästi pärtlipäev. Sellisel juhul saab rahvajutte pärtlirajust võtta kui andmeallikat, mis annab meile vihjeid antud perioodi ilmastiku kohta.

Pärtliraju pärimuse ajaloo analüüs nõuab aga põhjalikku tööd arhiivides ja kirjandusmuuseumi kogudes. Autorile kätte sattunud nii öelda avalikest allikatest (kirjandus ja internetiallikad: kodulehekülg Eesti Rahvaluule (www. folklore.ee); digitaalarhiiv DIGAR (www.digar.ee) ja selle eesti artiklite portaal (dea.digar.ee)) jääb pärtliraju eestistumisest mõneti vastuoluline pilt, mille alusel võib spekuleerida, et pärtliraju traditsioon on pigem suhteliselt hiline laen. Huvitav on näiteks täheldada, et raamatus "Eesti kliima minevikus ja tänapäeval" (Tarand et al. 2013), millest suurema osa hõlmavad Andres Tarandi poolt kogutud ja analüüsitud kroonikate ja vanade ajalehtede tsitaadid, pole ühtegi märget pärtlirajust. Pärtlipäeva on mainitud üksnes kolmel korral (aastatel 1640, 1642 ja 1878) ning seda vaid väga varajaste öökülmade kontekstis. Pärtlipäeva pole märkimisväärseks pidanud ka meie esimesed rahvakultuuri uurijad. Näiteks Jung (1879) kirjutab küll pärtlipäevast, kuid raju ei maini. Umbes samal ajal kui Soomes õppinud Gustav Suits luuletas lehti roobitsevast pärtlirajust (Suits 1913), kirjutas Gustav Vilbaste põhjaliku ülevaate Kolga rannarahva hulgas tähistatud rahvakalendri tähtpäevadest (Wilberg 1913). Muuhulgas mainitakse ära pärtlipäev kui üks jaanipäevale järgnev vähemtähtis tähtpäev. Rannarahvale potentsiaalselt ohtlikust pärtlirajust Vilbaste ei kirjuta. Samas on Kuusalu kihelkonnast siiski teada pärtliraju ülestähendusi (joonis 1). Tormi ja suurt vett kardeti Kolgal hoopis risti ümber, s.t ristipäeva ehk taevaminemispüha paiku (Wilberg 1913). Ja samas, nagu sissejuhatuses mainitud, alustas Viru-Nigula kihelkonnas sündinud ja seal lapsepõlve veetnud Jüri Parijõgi jutustust "Hingi päästmas" just pärtliraju kirjeldusega.

Esimene ajaleheartikkel, mis viitab pärtlipäevaga seotud tuulisele ilmale, on dea.digar.ee otsimismootori järgi tuvastatav 4. septembrist 1890. Siis ilmus ajalehes Tallinna Sõber 27. lõikuskuu päeval Paldiskist postitatud kiri, milles teatatakse, et pärast suurt maru on ilm mõneks päevaks ilusaks läinud, kuid nüüd tuul jälle tugevneb: "Meie omad pääsukesed on juba väga arvaks läinud, nagu ikka kohe pärast Pärtli pääva. Tuuled teevad suwe lahkumiseks vägewat kontserti." 1895. aasta 31. augusti Postimehes kirjutatakse sellest, kuidas Virumaal kohe pärtlipäeval linnud kadusid ja lehed kolletama hakkasid. Otseselt tormist küll juttu ei ole, kuid mainitakse, et ilmad on sügisesed ja 13.-27. augustini sadas pidevalt vihma. 26. augustil 1897 aga avaldatakse Postimehes kiri Viljandimaalt, milles kiidetakse vihmarikast ja sooja suve ning antakse teada, et kaks öökülmaohtlikku püha, lauritsa- ja pärtlipäev, möödusid sel aastal ilma külmata. 1902. aasta 24. augusti Postimehes aga kurdetakse Suure-Jaanist, et ka vanemad inimesed ei mäleta, et rukist lõigataks pärast 
pärtlit, nagu sel viletsal suvel juhtus. Pärtlipäeva mainitaksegi leheuudistes pigem rukkisaagi ja -külvi kontekstis.

Ja järsku ilmub juba sissejuhatuses mainitud 10. septembri 1929. a Virumaa Teataja, milles lisaks tormiõnnetuste kirjeldamisele on veel eraldi artikkel pärtlirajust:

"Ennem jääb pool talvet taeva, kui "Pärtli roju” tulemata", — nii ütleb vanarahwa ettekuulutus ja seda ka täie õigusega. Peaaegu iga aasta tabavad meid Pärtli päeva (25. aug. v. k.) ümbruses tugevad sajud ja tormid. Eriti tormiseks ja tugevaks osutus tänavune "pärtli roju”, mis vihma ja tugeva tormiga algas juba möödunud neljapäeval (s.o. 5. septembril). Harva möödub "pärtli roju” kuivade tormidega, enamasti alati seltsib tugev vihm, mis lakkamatult, nagu "kapaservast” alla kallub. [...] (kirjaviis muutmata).

Järgmisel aastal ilmus August Krikmanni (1930) sulest Virumaa Teatajas kirjatükk "Roju, rõmavihm ja kapsakaste". Selles toob tuntud õpetaja, arhivaar ja rahvapärimuse koguja näiteid pärtlirajudest juba Russowi kroonikast ning hilisemast ajast: "Pärtli tormides on Lontova sadamas ja mujal Viru rannas palju laevu hukkunud ühes meeskondadega. Ka möödunud aasta kapsakaste oli pärtlil õige rohke. Vihma valas kui hiigla kapa servast.” 26. augustil 1931 Virumaa randa ja angerjapüüki häirinud kirdetormi seostati samuti pärtlipäevaga (Vaba Maa, 29. august 1931). Sarnaseid uudiseid pärtlirajudest võib järgnevate aastate ajalehtedes üsna sageli trehvata ja nii jääbki mulje, et pärtliraju on midagi just 1930. aastate Eesti ilmastikule tüüpilist.

Sellisesse järeldusse tuleb muidugi suhtuda kriitiliselt. Ühelt poolt peab kiitma Eesti Rahvusraamatukogu poolt arendatavat digiarhiivi DIGAR, mis võimaldab lihtsat ligipääsu ja otsingut vanadest raamatutest ja ajalehtedest. Teiselt poolt pole käesoleva artikli kirjutamise ajal veel kõiki enne Teist maailmasõda ilmunud raamatuid ja ajalehti digitaliseeritud. Lisaks sõltub DIGARI otsingumootori võimekus raamatutest või ajaleheartiklitest märksõnu üles leida suuresti teksti trükkimise ja digitaliseerimise kvaliteedist. Seega ei pruugi ainult elektroonse otsinguga kõik, eriti aga vanemad teated pärtlirajust välja tulla.

Teadete domineerimist 1930. aastatel saab seletada veel ühe tendentsiga. Nimelt alustasid kahe maailmasõja vahel ilmumist mitmed uued maakonnalehed, millel oli suur huvi ilmastikunähtuste vastu; seda eriti nn vaikival ajastul (vt Tarand 2004: tabel 1). 1925. aastal asutati Virumaa Teataja, mis oli esimene peaaegu kogu Virumaad hõlmav päevaleht. Kui 19. sajandi suured Eesti ajalehed sõltusid kohapealsetest kirjasaatjatest, siis maakonnalehed olidki niiöelda koha peal. Virumaa Teataja pööras üsna palju tähelepanu rannikuelule ja kalandusele (Sepp \& Pae 2016) ning ka ilmale. 


\section{Kokkuvõte}

Tuuleandmete analüüs ei anna lõplikku vastust küsimusele, kas selline nähtus, nagu pärtliraju, on tegelikult looduses olemas või mitte. Perioodil 1966-2012 Jõhvi ja Väike-Maarja ilmajaamas mõõdetud andmete alusel võib öelda, et augusti lõpp ja septembri algus on Virumaal pigem tuulevaikne periood. Sellise suhtelise tuulevaikuse taustal võib iga tuulisem päev tunduda rajuilmana.

Analüüs näitab ka, et viimastel kümnenditel on tuuliseid ilmasid jäänud üha vähemaks. See on märk nii Eesti maastike muutumistest, kuid peamiselt siiski kliimamuutustest. "Vanasti" olid august ja september kindlasti palju tuulisemad. Kuivõrd tuuline kirderannikul enne 1966. aastat pärtlipäeva ümbruses oli, vajab eraldi uurimist.

Omaette teema on see, mida annab selline ilmakõnekäändude analüüs. Varasemad ilmavanasõnade uurijad on sageli rahvatarkustesse suhtunud teatava üleolekuga. Praktilise ilmaennustuse alusena rahvatarkused tõesti ei päde. Samas pole seda teemat kuigi palju uuritud ei Eestis ega rahvusvahelisel tasemel.

Kindlasti on nii folkloristika kui ka ilmateadused Tõllasepa ja Taylori aegadest tublisti edasi arenenud. Potentsiaalselt annab ilmakõnekäändude uurimine teadmisi nii meie esivanemate maailmapildi, rahvatarkuse leviku, kui ka omaaegse ilmastiku kohta. Nende küsimuste selgitamine aga nõuab ilmateadlaste ja folkloristide tihedat koostööd.

\section{Tänuavaldused}

Autor tänab Anneli Baranit ja Peter Grzybekit ilmapärimuse kapist välja toomise ning anonüümseid retsensente heatahtlikkuse ja kasulike nõuannete eest. Artikli kirjutamisel on kasutatud Eesti Vabariigi Teadus- ja haridusministeeriumi uurimistoetuste IUT 2-16 ja PUT 1439 vahendeid.

\section{Allikad}

Kull, Ain 2017. Tartu Ülikooli geograafia osakonna loodusgeograafia vanemteadur. Isiklik suhtlus, materjalid artikli autori käes. 


\section{Ajalehed}

Postimees 31. august $1895=$ Kodumaalt. Virumaalt. Postimees 193, lk 3.

Postimees 26. august 1897 = Kodumaalt. Viljandi kihelkonnas Vana-Tänassilmas... Postimees 189, lk 2.

Postimees 24. august $1902=$ Kodumaalt. Suure-Jaanist. Postimees 187, lk 3.

Tallinna Sõber 4. september 1890 = Omalt maalt. Kange tormi... Tallinna Sõber 36, lk 3.

Uudisleht 29. august 1938 = Pärtliraju tegi ränka kahju. Põhjaranniku kalurid jäid ilma lõhe- ja angerjarüsadest. Uudisleht $\mathrm{nr} 132$, lk 12.

Vaba Maa 29. august 1931 = Torm ja kalurid Viru rannas. Vaba Maa 202, lk 8.

Virumaa Teataja 10. september 1929 = "Pärtli raju" sünnitas maal kahju. Vanarahva ennustus, mis korduvalt täide läheb. Virumaa Teataja nr 102, lk 2.

Virumaa Teataja 10. september 1937 = Pärtliraju kahjutöö Virumaal ja mujal. Virumaa Teataja nr 104, lk 3.

\section{Internet}

DIGAR. www.digar.ee; dea.digar.ee (29. mai 2017).

Eesti Rahvaluule. Kodulehekülg. www.folklore.ee (29. mai 2017).

Saareste = Andrus Saareste. Eesti mõistelise sõnaraamatu indeks. www.eki.ee/dict/ saareste/ (29. mai 2017).

Scopus. www.scopus.com (29. mai 2017).

Thomson Reuters Web of Science. www.webofknowledge.com (29. mai 2017).

VMS = Pall, Valdek. Väike murdesõnastik. Eesti Keele Instituut, sõnastikud. portaal. eki.ee/dict/vms (29. mai 2017).

\section{Kirjandus}

Ahven, Heino (koost) 1957. Pajatusi põhjarannikult. Valimik korrespondentide murdetekste II. Tallinn: [Eesti NSV Teaduste Akadeemia \& Emakeele Selts].

Baran, Anneli 2016. Weather Paremias - A Special Case of Proverbiality. Soares, Rui JB \& Lauhakangas, Outi (toim). 9th Interdisciplinary Colloquium on Proverbs. Tavira 01-08 Nov. 2015 Portugal. Tavira: Tipografia Tavirense, lk 315-327.

Chen, Deliang \& Achberger, Christine \& Räisänen, Jouni \& Hellström, Cecilia 2006. Using statistical downscaling to quantify the GCM-related uncertainty in regional climate change scenarios: A case study of Swedish precipitation. Advances in Atmospheric Sciences 23.1, lk 54-60 (doi: 10.1007/s00376-006-0006-5). 
Dundes, Alan 1984. On Whether Weather Proverbs are 'Proverbs'. Proverbium. Yearbook of International Proverb Scholarship, vol. 1, lk 39-46.

Grzybek, Peter 2016. On Whether Weather Proverbs Are Weather Proverbs. Soares, Rui JB \& Lauhakangas, Outi (toim). 9th Interdisciplinary Colloquium on Proverbs. Tavira 01-08 Nov. 2015 Portugal. Tavira: Tipografia Tavirense, lk 273-290.

Hazen, Henry Allen 1900. The Origin and Value of Weather Lore. Journal of American Folklore 13 (50), lk 191-198 (doi: 10.2307/533883).

Hiiemäe, Mall 1991. Eesti rahvakalender V. Tallinn: Eesti Raamat.

Hiiemäe, Mall 2007. Sõnajalg jaaniööl. Eesti mõttelugu 73. Tartu: Ilmamaa.

Hiiemäe, Mall 2010. Pühad ja argised ajad rahvakalendris. Tallinn: Varrak.

Hiiemäe, Mall 2015. Torm ja tuisk, raju ja maru rahvameteoroloogias. Eesti Loodus 1, lk 40-43.

Hirschfelder, Gunther 2012. Ekstreemsed ilmastikunähtused ja kliimamuutused kultuuriteooria vaatenurgast. Hiiemäe, Reet (koost). Mis on ühist Gilgamešil ja geeniuurimisel? Käsitlusi kultuurist ja usundist. Tartu: EKM Teaduskirjastus, MTÜ Eesti Folkloori Instituut, lk 231-248.

Huff, Darrell 1954. How to lie with statistics. New York: Norton.

Hussar Anne \& Krikmann, Arvo \& Normann, Erna \& Pino, Veera \& Sarv, Ingrid \& Saukas, Rein (koost) 1983. Eesti vanasõnad II. Monumenta Estoniae Antiquae. Tallinn: Eesti Raamat.

Jung, Jaan 1879. Eesti rahwa wanast usust, kombedest ja juttudest. Tartu: H. Laakmann. Järv, Risto 1997. Tarbetarkusest argiarvamuseni, vahel vanasõnaks välja? Hiiemäe, Mall \& Oras, Janika (toim). Maa ja ilm. Pro Folkloristica 5. Tartu: Eesti Kirjandusmuuseum, lk 26-42.

Kaasik, Marko 2003. Kas Eesti talved on ennustatavad? Jaagus, Jaak (toim). Uurimusi Eesti kliimast $=$ Studies on climate of Estonia . Publicationes Instituti Geographici Universitatis Tartuensis 93. Tartu: Tartu Ülikooli Kirjastus, lk 164-177.

Keevallik, Sirje 2011. Tuulevälja muutumine Läänemere kirdeosas viimase poolsajandi jooksul. Soomere, Tarmo \& Nõges, Tiina (toim). Meri. Järved. Rannik. Teadusmõte Eestis VII. Tallinn: Eesti Teaduste Akadeemia, lk 49-58.

Krikmann, Arvo 2001. Sissevaateid folkloori lühivormidesse. 1. Tartu: Eesti Kirjandusmuuseum (http://www.folklore.ee/ kriku/LEX/KATUS.HTM - 29. mai 2017).

Krikmann, A[ugust] 1930. Roju, rõmawihm ja kapsakaste. Virumaa Teataja nr 8, 23. jaanuar, $1 \mathrm{k} 4$.

Niilas, Niilo 1936. Pärtliraju (katkend). Eesti Noorus 9, september 1936, lk 295-297.

Pae, Taavi \& Tammiksaar, Erki 2016. August Tõllassepp - Eesti esimesi meteorolooge. Post, Piia \& Järvet, Arvo \& Tammiksaar, Erki (toim). Tartu Ülikooli Ilmade Observatooriumi 150. aastapäeva konverentside artiklid = Articles of the conferences dedicated to the 150th anniversary of Meteorological Observatory of University of Tartu. Publicationes Geophysicales Universitatis Tartuensis 51. Tartu: Tartu Ülikooli Kirjastus, lk 49-60. 
Parijõgi, Jüri 1927. Hingi päästmas. Laevapoisi päivilt. Tallinn: Eesti Õpetajate Liit \& Tallinna Eesti Kirjastus-Ühisus.

Proodel, Mall \& Mürk, Heino 1970. Vanarahva tähelepanekud ilmast. Tooming, Heino (koost). Inimene ja ilm. Tallinn: Valgus, lk 165-171.

Sepp, Mait 2013a. "Enne jääb pool talve taevasse, kui jääb ära pärtliraju”. Eesti Loodus 8, lk 40-43 (http://www.eestiloodus.ee/arhiiv/Eesti_Loodus08_2013.pdf - 22. mai 2017).

Sepp, Mait 2013b. Ilmavanasõnad ja ilmastikuteadus. Eesti Loodus 9, lk 21-25 (http:// www.eestiloodus.ee/arhiiv/Eesti_Loodus09_2013.pdf - 29. mai 2017).

Sepp, Mait \& Pae, Taavi 2016. Purtse jõe reostamine - saaga algus. Järvet, Arvo (toim). Eesti Geograafia Seltsi aastaraamat 41. Tallinn: Eesti Geograafia Selts, lk 81-105.

Smits, A. \& Klein Tank, Albert M. G. \& Können, Günther P. 2005. Trends in storminess over The Netherlands, 1962-2002. International Journal of Climatology 25, lk 1331-1344 (doi: 10.1002/joc.1195).

Suits, Gustav 1913. Tuulemaa. Luuletused 1905-1912. [Tartu]: Noor-Eesti.

Tarand, Andres 2004. Kaks sajandit ilmaselgitamist Eestis. Akadeemia 9 (186), lk 2019_ 2056.

Tarand, Andres \& Jaagus, Jaak \& Kallis, Ain 2013. Eesti kliima minevikus ja tänapäeval. Tartu: Tartu Ülikooli Kirjastus.

Taylor, Archer 1931. The Proverb. Cambridge: Harvard University Press.

Tedre, Ülo 2015. Eestlaste argielutavadest. Mäetagused 61. Ülo Tedre artikleid, lk 91110 (http://www.folklore.ee/tagused/nr61/tava.pdf, doi: 10.7592/MT2015.61.tava).

Tehver, Gea 1999. Talve ja kevade ilmastikutüübid Eestis ning nende vaheline seos. Jaagus, Jaak (toim). Uurimusi Eesti kliimast. Publicationes Instituti Geographici Universitatis Tartuensis 85. Tartu, lk 74-85.

Tomingas, Oliver 2002. Relationship between atmospheric circulation indices and climate variability in Estonia. Boreal Environment Research 7.4, lk 463-470 (http://www. borenv.net/BER/pdfs/ber7/ber7-463.pdf - 29. mai 2017).

Toomeos-Orglaan, Kärri 2003. "Kinder- und Hausmärchen" eesti imemuinasjuttude allikana. Hiiemäe, Mall \& Labi, Kanni (toim). Teekond. Pro Folkloristica X. Tartu: Eesti Ajalooarhiiv \& Eesti Kirjandusmuuseum, lk 183-196.

Toomeos-Orglaan, Kärri 2011. Seitsme maa ja mere tagant? Küsimusi imemuinasjuttude päritolust. Vikerkaar 26, lk 78-89.

Tõllasepp, August 1920. Vanasõnad ilmadest. Tallinn: Rahvaülikool.

Tõllasepp, August 1960. Meteoroloogia kõigile. Tallinn: Eesti Riiklik Kirjastus.

Under, Marie 1931. Leedi. Looming 8, oktoober, lk 777-778.

Vautard, Robert \& Cattiaux, Julien \& Yiou, Pascal \& Thépaut, Jean-Noël \& Ciais, Philippe 2010. Northern Hemisphere atmospheric stilling partly attributed to an increase in surface roughness. Nature Geoscience 3.11, lk 756-761 (doi: 10.1038/ngeo979).

Viires, Ants 1993. Kuude nimetused eesti keeles. Keel ja Kirjandus 2, lk 73-86. 
Vilbaste, Gustav 1944. Rahvapäraseid ennustusi viljasaagi kohta. Eesti Sõna, 30. mai, lk 4 .

Wilberg, Gustav 1913. Endised tähtpäewad Kolga Rannas. Reiman, Villem (koost, toim). Eesti kultura II. Postimehe kirjakogu, lk 263-279.

Mait Sepp - Tartu Ülikooli loodusgeograaf, klimatoloog.

mait.sepp@ut.ee

\section{Summary}

\section{On St. Bartholomew's Day storm and weather paroemias}

Mait Sepp

Keywords: climate change, folk tradition, St. Bartholomew's Day, St. Bartholomew's Day storm, weather paroemias, wind speed

The present study analyses St. Bartholomew's Day storm - a storm that supposedly takes place near St. Bartholomew's Day (August 24th) every year - a paroemia that has widely spread on the north-eastern coast of Estonia. The two questions analysed here are: firstly, whether such a storm is proved by the meteorological data and, secondly, whether it is reasonable to study weather paroemias.

The present research makes use of the data about wind speed, measured in Jõhvi and Väike-Maarja weather stations during the period from 1966 to 2012. A more detailed analysis is dedicated to wind data around the old St. Bartholomew's Day - the period around September 7th by the Gregorian calendar (August 12th till September 20th).

According to wind speed data, it may be said that in north-eastern Estonia the end of August and beginning of September are rather windless. However, the analysis of the wind measurement data does not give a definitive answer to the question whether such a phenomenon as St. Bartholomew's Day storm actually exists in nature. Against the background of relatively windless days, every windier day may be seen as stormy.

The analysis indicates that the number of windy days around St. Bartholomew's Day has constantly been decreasing over the last decades. This refers to changes in Estonian landscape, but even more so to changes in the climate. In the olden times, August and September were definitely much windier than today. Further research is needed to find out how windy the north-eastern coast of Estonia was around St. Bartholomew's Day in the period before 1966 .

What is the benefit of such an analysis of weather paroemias? Proverb researchers have often viewed weather folklore somewhat condescendingly. It is true that weather paroemias do not qualify as the basis of scientific synoptic meteorology, and many paroemias have been borrowed from other cultures. For example, it is known that the St. Bartholomew's Day storm tradition is Germanic and has reached Estonia via Fin- 
land. Weather paroemias, including weather proverbs, do not often follow the classical proverb rules. This is probably the reason why weather paroemias have been thoroughly studied neither in Estonia nor internationally.

A study into weather proverbs potentially gives us knowledge about the worldview of our ancestors, culture distribution mechanisms, and also about the weather in the past. For example, it may be speculated that borrowed paroemias that fitted into the local population's worldview or helped to better explain local weather phenomena entered common usage. If this is true, then it should be possible to find out from archived data when a particular weather paroemia became popular. This, in turn, enables us to use weather paroemias as proxy data for weather sciences. It may be assumed on the basis of old newspapers that the term St. Bartholomew's Day storm became widely spread in the 1920s through to 1930 s, when several well-documented storms indeed had devastating effects on the coast of north-eastern Estonia. However, this assumption has to be taken as a speculation, as several county newspapers, whose interest in the local weather was great, were established within the same period. A more detailed analysis of the St. Bartholomew's Day storm tradition and other weather paroemias, however, requires a close cooperation between atmospheric scientists and folklorists.

Mait Sepp is Research Fellow in physical geography at the University of Tartu.

mait.sepp@ut.ee 